\title{
Az ukrán oktatáspolitika hatása a kárpátaljai magyar tannyelvü felsőoktatásra
}

\author{
Pallay Katalin*
}

A kisebbségi oktatás és az arra gyakorolt oktatáspolitika vizsgálata kiemelten fontos szerepet játszik, ugyanis sajátos erótérben mozognak (Kozma, 2012). Jelen tanulmány a rendszerváltástól napjainkig (1991-2018) mutatja be az ukrajnai oktatáspolitikát. Fel szeretnénk tárni, hogyan alakult az ukrán oktatáspolitika az Európai Uniós normák felé közeledés során, s ezek a törekvések mennyire voltak sikeresek. Munkánkban meg kívánjuk vizsgálni, hogy a különböző politikai fordulatok milyen hatást gyakoroltak az ukrán állam kisebbségpolitikájára és ezen belül a kárpátaljai magyarokra. A föbb irányelveket és tendenciákat kívánjuk az olvasó elé tárni. Az ukrajnai oktatáspolitikát a kisebbségi nemzeti közösségek szempontjából kettősség jellemzi: egyszerre figyelhető meg az európai hatás és az ukránosítás. A politikai és gazdasági változások során számos pozitiv célkitüzést hajtottak végre az oktatáspolitika terén. Ide sorolhatók az Európai Unió felé nyitó lépések, mint például a Bolognai-rendszerhez történő csatlakozás. Az ország oktatáspolitikai szempontból az Európai Unió felé törekszik, eredményeim szerint azonban a kisebbségi nemzeti közösségek jogait illetően visszafejlődés tapasztalható.

Kulcsszavak: oktatáspolitika, kisebbségi nemzeti közösségek, Ukrajna

\section{Oktatási helyzet és oktatáspolitika a rendszerváltás éveiben}

\section{A rendszerváltás oktatásra gyakorolt hatása. Kisebbségpolitika és jogi szabályozás}

A rendszerváltás előszeleként értelmezhető Mihail Gorbacsov kinevezése a Szovjet Kommunista Párt főtitkári székébe (1985), akinek eredménytelen reformkísérletei a Szovjetunió és az államszocialista rendszer bukásához vezettek. 1990 márciusában Gorbacsovot a Szovjetunió elnökévé választották. Gorbacsov feloszlatta az állampártot. A moszkvai puccs okozta kaotikus belpolitikai helyzetben a kijevi törvényhozás, az ún. Legfelsőbb Tanács 1991. augusztus 24-én kinyilvánította Ukrajna függetlenségét. Az aktust a december 1-jei referendum legitimálta. Ez azonban nem jelentett teljes rendszerváltást, hiszen az ukrán politikai és gazdasági életben to vábbra is jelentős befolyással rendelkeztek az egykori kommunista káderek. A referendum napján tartott elnökválasztás győztese Leonyid Kravcsuk lett (Jekelcsik, 2014). A rendszerváltás okozta nehézségek negatívan befolyásolták az oktatás világát. A rendszerváltást követő években létrejött nagymértékú infláció az oktatást is mély válságba sodorta, az oktatási intézményeknek nehezen kezelhető költségvetéssel kellett szembenézniük, a pedagógusok hónapokig nem kapták meg bérüket. Ezekben az években a politikai elit figyelme a belpolitikai harcokra, illetve a soron következő elnökválasztásra terjedt ki. 1993-96 között az országot sújtó politikai és gazdasági válság miatt pénzelvonás nehezítette az oktatási szféra múködését, melynek következtében elképzelhetetlen lett volna új reformlépéseket tenni, s a megkezdett újításokat sem tudták kivitelezni (Szamborovszky, 2013).

\section{A rendszerváltás és a kisebbségpolitika}

1996. június 28-án a Legfelsőbb Tanács elfogadta Ukrajna Alkotmányát. Az alkotmány értelmében az ország egynyelvŭ, az államnyelv az ukrán (Web1). A függetlenné vált Ukrajna oktatáspolitikája kezdetben a végleg 
megszűnt Szovjetunió oktatáspolitikájának jegyeit viselte magán. Még a függetlenség kikiáltása előtt kialakult az oktatáspolitikának egy olyan törvényi háttere, melyek évtizedekig életben voltak: Ukrajna elnökének törvényerejü rendeletei és rendelkezése (Web2), Ukrajna Alkotmánybíróságának végzése (Web3), Ukrajna Miniszteri Kabinetjének határozatai (Web4), illetve Ukrajna Oktatási és Tudományos Minisztériumának rendeletei és határozatai (Web5).

A Legfelsőbb Tanács 1991. június 4-én fogadta el Az oktatásról szóló törvényt (34. számú törvény, Web6), amely tartalmazta az oktatói és nevelői munka fejlesztési lehetőségeit, a pedagógusok jogait és kötelezettségeit, az oktatási intézmények múködtetési és igazgatási rendszerét (Szamborovszky, 2013). Az oktatási törvény a szovjet időszakhoz hasonlóan biztosította a nemzeti kisebbségek számára a teljeskörú anyanyelvi oktatást.

1996 májusában, miután Ukrajna csatlakozott az Európa Tanácshoz, Strasbourgban aláírta A regionális vagy Kisebbségi Nyelvek Európai Kartáját (Web7). A dokumentumot Ukrajna Legfelsőbb Tanácsa 1999 decemberében ratifikálta. Még ebben az évben megszületett a Karta ratifikációjáról szóló 1350-XIV. számú törvény (Web8). Ennek értelmében Ukrajnában az orosz, a héber, a belorusz, a moldáv, a román, a krími tatár, a bolgár, a len gyel, a magyar, a görög, a német, a gagauz és a szlovák nyelvekre terjesztik ki a Karta által vállalt rendelkezéseket. A Karta ratifikációját 2000-ben a hatálybalépés ügyrendi hibáira hivatkozva Ukrajna Alkotmánybírósága alkotmányellenesnek nyilvánította, így gyakorlati életbelépése nem valósult meg. Számos új törvénytervezet született a Karta ratifikálására vonatkozóan. 2003-ban Leonyid Kucsma köztárasági elnök aláírta a Legfelsőbb Tanács által elfogadott törvénytervezetet, amely hatályba is lépett (N 802-IV. számú törvény (Web9). A törvény 8. cikkelye terjed ki az oktatásra, amely értelmében az Ukrajnában élő kisebbségeknek joguk van az anyanyelvi oktatáshoz az oktatási folyamat különböző szintjein, amennyiben családjaik ezt kívánják, az adott területen elegendő a létszámuk és engedélyezik a kisebbségi nyelven folyó felsőoktatási intézményben történő oktatást, illetve tanulást (Beregszászi \& Csernicskó, 2007).

1997 májusában Csernyivciben (Csernovic) oktatási konferenciát rendeztek, melyen az Ukrán Oktatási Minisztérium képviselői bemutatták a nemzeti kisebbségek oktatására vonatkozó terveket. A kisebbségi jogokat szűkítő tervezet nagy tiltakozást váltott ki. Ennek hatására többször módosították, de nem változtatták meg az ukrán nemzetállam megteremtését célzó koncepciót. Ennek értelmében ún. átirányításos, tranzitív oktatási modellel kívánták oktatni a nemzeti kisebbségi közösségben élőket, amely szerint a kisebbségi gyereket alsó tagozaton anyanyelvén oktatnák, majd fokozatosan áttérnének a többségi nyelvi oktatásra. A tervezet egyetlen módosított változatát sem küldték el az illetékes kisebbségi érdekvédelmi szervezeteknek és azok legitim állami képviselőinek. A dokumentum nem vette figyelembe az érvényben lévő törvényeket, de végül az oktatási minisztérium szakmai tanácsadó testülete nem tűzte napirendre (Orosz, Beregszászi, Csernicskó \& Bátyi, 2011).

A független Ukrajnában 2001 decemberében volt az első és napjainkig egyetlen népszámlálás. Korábban 1989-ben tartottak népszámlálást, ami össz-szövetséginek nevezett szovjet összeírás volt (Molnár \& Molnár, 2005). A népszámlálási adatokat elemző tanulmányok kimondják, hogy Ukrajnában 130 különböző nemzetiség él. A két legnagyobb nemzet az ukrán és az orosz (Csernicskó \& Melnyk, 2007). A 2001-es népszámlálás adatai alapján Ukrajna nemzetiségi megoszlása a következő: 


\begin{tabular}{|lr|}
\hline \multicolumn{1}{|c|}{ Nemzetiség } & 37541693 \\
\hline Ukrán & 8334141 \\
\hline Orosz & 275763 \\
\hline Belorusz & 258619 \\
\hline Moldáv & 248193 \\
\hline Krími tatár & 204574 \\
\hline Bolgár & 156566 \\
\hline Magyar & 150989 \\
\hline Román & 144130 \\
\hline Lengyel & 103591 \\
\hline Zsidó & 99894 \\
\hline Örmény & 91548 \\
\hline Görög & 73304 \\
\hline Tatár & 45176 \\
\hline Azerbajdzsán & 34199 \\
\hline Grúz & 33302 \\
\hline Német & 31923 \\
\hline Gagauz & 12353 \\
\hline Üzbég & 10593 \\
\hline Csuvas & 6397 \\
\hline Szlovák & 323656 \\
\hline Egyéb & $n y k, 2007$ \\
\hline népszámlálás adatai alapján. Forrás: Csernicskó \& Mel- \\
\hline
\end{tabular}

A kisebbségek oktatásának helyzete bonyolult egy soknemzetiségű országban, mert a különböző régiók ok tatáspolitikusai más-más álláspontot képviselhetnek. Ukrajnában a kisebbségek oktatását tekintve különösen megnehezíti, hogy az országban erősen centralizált oktatási rendszer van érvényben, melynek értelmében a ki sebbségi oktatás nem élvez önállóságot (Orosz, 2005, 2007). Ennek eredményeként a kisebbségi oktatás miatt nemzetépítő ellentétek alakulnak ki: míg az állam nemzeti többség megerősítésére törekszik, addig a nemzeti kisebbség az oktatás segítségével kívánja megerősíteni nemzeti identitását. A kisebbségi oktatási intézmények múködése az anyanyelv megőrzésének funkciója mellett asszimiláció elleni küzdelmet is jelent (Papp Z., 2014).

\section{A kárpátaljai magyar kisebbségek oktatása a független Ukrajnában}

Egy adott országban oktatott idegen tannyelv képet ad arról, hogy az országban a hatalom melyik társadalmi osztálynak kíván kedvezni, illetve melyik csoportnak kívánja szúkíteni a jogait. A tannyelvpolitika azt vizsgálja, hogy hogyan viszonyulnak egymáshoz az országban beszélt nyelvek, milyen a nyelv gyakorisága, hogyan ala- 
kulnak az adott országban a nyelvi jogok. A tannyelvpolitika az oktatás nyelvére, az oktatott tannyelvek kap csolatára és a tannyelv szabályozására irányul (Vámos, 2016).

Ukrajnában a rendszerváltás több dimenzióban hatott a kisebbségi oktatáspolitikára. Pozitívumként emelhető ki, hogy közvetlenül a rendszerváltás előtt és a rendszerváltást követő években létrejövő kisebbségi jogokat meghatározó törvények és rendeletek viszonylag toleránsak voltak az országban élő nemzeti kisebbségekkel szemben. Ezt igazolja, hogy a nyolcvanas évek végén és a kilencvenes évek elején létrehozott törvények engedélyezték az anyanyelv használatát az oktatás minden szintjén. Az 1990-es évek elején lehetővé tették, hogy az államnyelv mellett hivatalos nyelvként használják a kisebbségi nyelvet.

Ukrajna Alkotmánya (Web10) (1996) kimondja, hogy az ország területén szavatolt a nemzeti kisebbségek nyelvének használata és védelme (Orosz, 2005). 1992. június 25-én fogadták el Ukrajna nemzeti kisebbségi közösségekről szóló törvényét. A törvény 6. cikkelye biztosítja az anyanyelven történő oktatást, az anyanyelv tanulását az állami fenntartású oktatási intézményekben (36. számú rendelet (Web11)). A máig hatályban lévő jogszabályt 1996-ban módosították, melynek 6. cikkelye minden Ukrajnában éló állampolgár számára garantálja az oktatás minden formájának hozzáférhetőségét. Ennek tükrében a nemzeti kisebbségi közösségek számára is biztosított az anyanyelvi oktatás (Orosz, 2005).

Ukrajnában az orosz, a román, a moldáv és az Ukrajna nyugati résszén elterülő Kárpátalján élő magyarok rendelkeznek olyan kiépült iskolarendszerrel, ahol az oktatás anyanyelven történik és heti több órában oktatják az államnyelvet, illetve kevesebb óraszámban egy idegen nyelvet (Orosz, 2005).

A kárpátaljai magyarság szempontjából a rendszerváltás egyik legfontosabb eleme, hogy Magyarország elismerte Ukrajnát független államként, ennek kapcsán megnyíltak a külképviseletek és 1991 decemberében megkötötték a magyar-ukrán alapszerződést (Web12). A szerződés leszögezi, hogy meg kell teremteni a nemzeti kisebbségek kulturális, nyelvi és vallási identitás védelmének biztosítására irányuló feltételeket (Fedinec, 2012). Pozitívumként kiemelhető, hogy megnyíltak a határok, megnövekedett a magyar tannyelvú iskolák száma, lehetővé vált a politizálás, a szervezkedés, a nemzeti szimbólumok használata. Mindennek következtében a kárpátaljai magyar fiatalság számára több lehetősége nyílt az anyanyelven folytatott továbbtanulásra. A függetlenség kikiáltása előtt, 1989-ben megalakult a Kárpátaljai Magyar Kulturális Szövetség (KMKSZ), a kárpátaljai magyarság első átfogó nemzetiségi, érdekképviseleti szervezete. A szövetség céljai között szerepel az anyanyelvi múvelődés és az oktatás elősegítése. $E$ cél megvalósítása érdekében létrehozták a KMKSZ Oktatási Bizottságát. Mivel az oktatás területén számos megoldatlan probléma állt fenn, a bizottság megalakított egy külön egyesületet, ami kizárólag az oktatás szakmai és politikai kérdéseivel foglalkozik. Ennek eredményekép pen jött létre 1991. december 8-án a Kárpátaljai Magyar Pedagógusszövetség (KMPSZ) (Orosz, 2007, 2012).

A függetlenség kikiáltását követő években Kárpátalján két nagy periódust különíthetünk el a magyar nyelvi felsőoktatás szempontjából: az egyik 1990, mikor a kárpátaljai magyar fiatalok számára lehetővé vált a magyarországi továbbtanulás, a másik pedig 1993, mikor önálló magyar nyelvű tanárképző főiskola létrehozásáról fogalmazódott meg gondolat (Orosz, 2012). 


\section{Felsőoktatási expanzió}

A kisebbségi felsőoktatási intézmények kiemelten fontos szerepet játszanak, hiszen azok gondoskodnak a kisebbségi helyzetben élő közösség értelmiségéről és tudományos elitjéről (Bacskai, Morvai \& Csánó, 2015). A rendszerváltás nemcsak az ukrajnai oktatáspolitikára gyakorolt nagy hatást, hanem Európa más országaiban is változások történtek az oktatás terén. Az 1990-es években az oktatáspolitika súlypontja a felsőoktatásra terelődött (Kozma, 2010). Az országhatárok megnyílásával fény derült a határmenti területeken a fokozott elmara dottságra, a határokon átnyúló kapcsolatok megromlására. A 1990-es években felsőoktatási reformok zajlottak, s határokon túlra kiterjedő oktatási kapcsolatok alakultak ki. Ez idő tájt a közép-európai kisebbségek egyik legfontosabb politikai folyamata az intézményesülés volt (Bárdi \& Misovicz, 2010). Létrejött a felsőoktatás tömegesedése, azaz a felsőoktatási expanzió. A jelenség a magyar oktatáspolitikára és a külhoni felsőoktatásra is kiterjed. Ennek hatására születtek meg a kisebbségi egyetemek. A kisebbségi felsőoktatási intézmények létrejöttéhez - attól függően, hogy az adott időszakban támogatta-e őket az anyaország támogatáspolitikája - mindig anyaországi felsőoktatási intézmények járultak hozzá. Az akkori támogatáspolitikáról szóló elgondolás szerint Magyarország támogatja az intézményalapítást, az intézmények működtetését pedig a kisebbségi társadalom végzi majd (Kozma, 2011; Bárdi \& Misovicz, 2010). Kozma (2006) a felsőoktatás terén az 1990-1994 közötti időszakot történelmi pillanatnak nevezi, melyben hatalmi vákuum alakult ki. Ebben a helyzetben civil kezdeményezéseket indítottak. Számos egyetemalapító indítványt készítettek a magyarországi felsőoktatási intézmények, a határon túli magyar egyházak, önkormányzatok és alapítványok. A KMKSZ igényeinek megfelelően magyarországi felsőoktatási intézmények kihelyezett képzéseket indítottak a határon túli felsőoktatási intézmények bázisán (Kozma, 2006; Kalóczi \& Kulcsár, 2016; Papp, 2014).

Ukrajnában a felsőoktatási változások hullámokban mentek végbe. Ez azzal magyarázható, hogy nem csu pán a felsőoktatás rendszerét kellett átalakítani, hanem az államszerkezetet is, hiszen gyakorlatilag új állam jött létre. A Szovjetunió széthullásával, az 1990-es évek elején alakult ki olyan politikai helyzet Ukrajnában, amely lehetővé tette a kárpátaljai magyar közösség számára, hogy önálló magyar tannyelvű felsőoktatási intézményt alapítsanak. Erre az igényre kedvezően hatott a felsőoktatási expanzió folyamata Magyarországon és a környező államokban. A magyar tannyelvű felsőoktatási intézmények létrehozása jól beleillett a felsőoktatás tömege sedésének folyamatába (Ferenc, 2010, 2011; Kozma, 2006). 1993-ban a Kárpátaljai Magyar Kulturális Szövetség és a Kárpátaljai Magyar Pedagógusszövetség együttes ülésén egy kárpátaljai magyar tannyelvű tanárképző főiskola létesítéséről hozott döntést. 1993 decemberében megalakult és bejegyezték a Kárpátaljai Magyar Fő iskoláért Alapítványt (KMFA). Az alapítvány célja a magyar tannyelvű főiskola anyagi bázisának megteremtése, az intézmény létrehozása, az alapszabályok bejegyzése és akkreditációja (Csernicskó, 2014).

A beregszászi főiskola tárgyi és személyi feltételeit nem lehetett volna megteremteni Magyarország hathatós anyagi támogatása nélkül. Az oktatás személyi feltételeit és a képzés tartalmi részét a nyíregyházi Bessenyei György Tanárképző Főiskola (BGYTF) biztosította. A KMFA és a BGYTF speciális tanárképzés beindításáról, vagyis nem nappali és nem is levelező képzésről kötött megállapodást. A tárgyi feltételeket a KMFA biztosította (Orosz, 2007).

A beregszászi főiskola tanárképző intézetként kezdte meg működését. A nemzeti kisebbségek által lakott településeken kiemelten fontos szerepet játszanak a kisebbségi oktatási nyelven folyó tanár- és tanítóképző intézetek. Az intézetek jelentősége abban ragadható meg, hogy növelik kisebbségi területen a diplomások számát, továbbá megteremtik az anyanyelvi oktatás feltételeit, illetve az alap- és középfokú oktatás minőségéért 
is felelősek (Keller, 2004). A rendszerváltást követő években létrejövő felsőoktatási politikák második fázisát Kozma (2006) a konszolidáció szakaszának nevezi. A kilencvenes évek második felétől az ezredfordulóig tartó időszakot a hatalmi elitek és civilek viszonyának megszilárdulása jellemezte. Ebben az időszakban Ukrajna fel sőoktatási politikája még centralizáltabb lett, s legfőbb ideológiája a nemzeti kultúra helyreállítása volt. A felsőoktatás terén is végbement a hatalmi átszerveződés, amely önállóságra, függetlenségre törekedett (Kozma, 2006).

\section{A narancsos forradalom után bekövetkező oktatáspolitikai változások}

A 2004-es elnökválasztási küzdelemben a korábbi elnök és az Oroszország bizalmát élvező Viktor Janukovics, illetve a nyugatbarát Viktor Juscsenko mérkőzött meg. A hivatalos választási eredmények minimális többséggel Janukovics győzelmét hozták. A Juscsenko és Julia Timosenko vezette ellenzék azzal vádolta meg Janukovicsot, hogy a kiélezett küzdelemben választási csalások sorozatának és megfélemlítésnek köszönhette győzelmét. Az elégedetlen ellenzéki tábor tüntetésekbe kezdett Kijev utcáin. Juscsenko kampányának szimbólumaként az optimizmust sugárzó narancssárga színt választotta, melynek nem volt kötődése az ukrán történelemhez. Az „Igen!” jelszóval indított mozgalom csakhamar az ún. narancsos forradalom elnevezést kapta, melynek egyik fő célja az új választások kírása volt. Ukrajna Alkotmánybírósága végül a „narancsosoknak” kedvező ítéletet hozott, s a választások megismételtetése mellett foglalt állást. A 2004. december 26-án megrendezett újabb megmérettetésben Juscsenkót választották elnökké. Ezzel győzött a narancsos forradalom (Jekelcsik, 2014).

A magyar állam továbbra is felelősséget vállalt az Ukrajnában élő magyar kisebbség oktatási, kulturális fejlő déséért. Az új ukrán államfő beiktatása alkalmából Mádl Ferenc, Magyarország akkori köztársasági elnöke így fogalmazott: „Magyar részröl többek között azért is követjük figyelemmel Ukrajna fejlödését, mert köztudott, hogy az ország polgárai között magyar nemzetiségúek is vannak. Az ukrajnai magyar kisebbség, oktatási, kulturális intézményei segítségével komoly erőfeszítéseket tesz szǔkebb pátriája fejlődése érdekébe..." (idézi Fedinec, 2012: 111).

A narancsos forradalmat követően Ukrajnában monolit nemzetállamot kívántak létrehozni. A legfőbb cél az ukrán államnyelv pozíciójának megerősítése volt. A nemzetépítésben kiemelten fontos szerepet kapott az államnyelv. Az ukrán politikai hatalom a nemzetállam építésére a leghatékonyabb eszközt az oktatásban látta. Az ukrajnai oktatási reformok az ukrán nyelv tanításának megerősítését célozták meg (Csernicskó, 2009). Ezekben az években Ukrajnát gyakorlatilag egynyelvű, ukrán nyelvű állammá kívánták változtatni. Az oktatáspolitikát e cél megvalósítása érdekében formálták. Az országban olyan oktatáspolitikai törekvések valósultak meg, amelyek arra irányultak, hogy a nem ukrán tannyelvú iskolák számára átirányítási (tranzitiv) oktatási modellt vezessenek be (Csernicskó, 2009).

\section{A Bolognai-folyamat hatásai Ukrajnában}

Kozma (2006) a felsőoktatás-politika változásainak harmadik szakaszát visszaállamosodásként definiálja. Ez a folyamat az 1990-es évek végén következett be. Az Európai Unióhoz történő csatlakozás nagy hatással volt Magyarország felsőoktatási politikájára (Kozma, 2006). A Bolognai- folyamathoz történő csatlakozás nagy hatással volt Ukrajna felsőoktatás-politikájára.

1999-ben Bolognában 29 ország oktatási minisztere írta alá a Bolognai Nyilatkozatot, ami által elindult a bolognai folyamatnak nevezett nagy felsőoktatási reform (Hrubos, 2005). Ukrajna 2005. május 19-én csatlako- 
zott a bolognai folyamathoz. A reformok eredményeképpen átalakították a felsőoktatás szerkezetét, de több elem megmaradt a szovjet oktatási rendszerből (Kovács, 2014).

Az ukrajnai felsőoktatási intézmények - az orvosi és állatorvosi képzések kivételével - a 2006/2007-es tanévre áttértek a European Credit Transfer System (ECTS) nevű kreditszámítási rendszerre (Luchinskaya \& Ovchynnikova, 2011). A Bolognai-folyamathoz történő csatlakozás egyik legfontosabb felsőoktatásra gyakorolt hatása, hogy átalakult a felsőoktatás struktúrája. A felsőoktatási képzést három szintre osztották fel:

1. Baccalaureus (BSc, BA, bakalavr);

2. Specialist (SSC);

3. Mesterképzés (MSc, magiszter).

1. Alapképzés - BSc-szint (bakalvr-képzés) - a főiskolák és egyetemek alapképzése, melyekre a külső független tesztvizsgák eredményeivel jelentkezhetnek az érettségivel rendelkező felvételizők. A képzés 4 éves, mely sikeres elvégzése után alapdiplomát kapnak a hallgatók.

2. Specialist szint - az alapképzés és a mesterképzés közé beékelődött egyéves képzés, amely sikeres elvég zése után a mesterfokozatú diplomával egyenértékủ oklevelet vehettek át a hallgatók (Orosz, 2012). Erre a képzési formára utoljára 2016-ban jelentkezhettek az alapdiplomával rendelkezők. 2017-ben a Specialist szintet végleg eltörölték. Másfél, illetve kétéves mesterképzés váltja fel. A BSc-/BA-képzést várhatóan három évesre szűkítik, de jelenleg négyéves képzésként működik (vö. Ukrajna felsőoktatási törvénye (Web13)).

3. Mesterképzés - (MSc, MA, magiszter), azok a hallgatók felvételizhetnek erre a képzési szintre, akik elvégezték az alapképzést és BSC/BA szintú diplomával rendelkeznek. Ezentúl Ukrajnában is ez a szint képzi a bolognai rendszer második fokát. Ez a mesterfokozat felel meg a bolognai rendszer bevezetése előtti egyetemi diplomának, amit az osztatlan egyetemi képzésben ötödik évfolyam után szerezhettek meg a hallgatók. A mes terszintű oklevél megszerzése után a diplomás fiatalok elhelyezkedhetnek a munkaerőpiacon, vagy PhD-képzésre jelentkezhetnek (Orosz, 2005).

A bolognai folyamathoz való csatlakozás számos oktatáspolitikai folyamatot indított el az országban. Egyrészt a korrupció visszaszorítása miatt, másrészt a középfokú oktatás minőségének emelése, valamint az ukrán oktatási rendszer az európai mintához való integrálása és a felsőoktatási intézményekbe történő egységes felvételiztetés céljából Viktor Juscsenko, Ukrajna elnöke 2005. július 4-én Az ukrajnai oktatás múködését és fejlődését biztosító elengedhetetlen intézkedésekről (Web14) adott ki rendeletet (Filiatreau, 2011). Az elnöki rendelet végrehajtására 2005-ben létrehozták az Ukrán Oktatásminőség-értékelő Központot, melynek célja, hogy felmérjék a felvételizők tárgyi tudását. A bolognai rendszerre hivatkozva egységes felvételi mechanizmust vezettek be. Ennek következtében független vizsgaközpontokban kell emelt szintű érettségi vizsgát, úgynevezett külső független tesztvizsgát tenni. Az újítás célja, hogy esélyegyenlőséget biztosítson a felvételi vizsgánál. Sztanyiszlav Nikolajenko, akkori ukrán oktatási miniszter 2007. július 13-án elrendelte, hogy a 2008/2009-es tanévben az ukrajnai továbbtanuláshoz minden felvételizőnek emelt szintű ukrán nyelv és irodalom tesztvizs gát kell tennie. Viktor Juscsenko véleménye szerint a fejlett európai állam létezésének feltétele az egységes ál lamnyelv (Csernicskó, 2012). Nikolajenko miniszter rendeletének értelmében a felvételizőknek az ukrán nyelv és irodalom emelt szintú érettségi mellé választhatóan szakiránynak megfelelően Ukrajna történelméből vagy matematikából is független tesztvizsgát kell tenni. A rendelet szerint minden felvételiző - a kisebbségi tannyel vú iskolák végzősei is - csak ukrán nyelven tehetik ezt meg. Ez a lépés jelentősen megnehezítette a kisebbségi, többek között a magyar tannyelvú iskolások esélyeit. Ivan Vakarcsuk, a következő oktatási miniszter 2007. december 25-én az 1171-es rendeletével (Web15) módosította elődje rendeletét, melyben a nemzetiségi iskolák végzősei számára szaknyelvi szójegyzet használatát engedélyezte. 2008. január 24-én kelt 33-as számú rende- 
let (Web16) ismét változásokat eredményezett, a kisebbségi tannyelvú iskolák tanulói a szakvizsgákat az okta tás nyelvén tehetik. Az ukrán nyelv és ukrán irodalom emelt szintú tesztvizsga továbbra is minden szakra köte lező felvételi vizsgatárgy. Pozitívumként tudható be, hogy leszámítva az ukrán nyelv és irodalom vizsgát, az egységes tesztvizsgák eredményei alapján meg lehet határozni a kárpátaljai magyar tannyelvú iskolák helyét az ukrán iskolarendszeren belül.

A 2010-es elnökválasztást Viktor Janukovics nyerte. A választást követően az oroszbarát Dmitro Tabacsnik lett az ukrán oktatási miniszter. Tabacsnik módosított a rendeleten, de jelentőségteljes változás nem következett be az oktatáspolitikában. A Janukovics által kinevezett kormány engedélyezte, hogy a szaktárgyakból lefordítsák az oktatás nyelvére a független tesztvizsgák kérdéseit. Az ukrán nyelv és irodalom emelt szintú érett ségi vizsga továbbra is minden szakra kötelező felvételi vizsgatárgy. Könnyítésként bevezették, hogy aki a szaktantárgyból 170 pontot szerez, abban az esetben is jelentkezhet felsőoktatási intézménybe, ha ukrán nyelvből és irodalomból nem érte el az alsó ponthatárt (Csernicskó, 2012; Orosz, 2015):

A külső független tesztelés nem biztosít esélyegyenlőséget a magyar anyanyelvú, magyar tannyelvű iskolások számára, ugyanis a vizsga követelményei teljes mértékben megegyeznek az ukrán tannyelvü iskolákban érettségizők, a nem államnyelven tanulók elé állított követelményekkel. Ennek hatására számos érettségiző Magyarországon folytatja tanulmányait. Ezzel a kárpátaljai diákok körében még inkább felerősödött a tanulmányi célú mobilitás. A külső független tesztelés bevezetését követő években csak azoknak az érettségizőknek kellett részt venni az emelt szintű tesztvizsgán, akik ukrajnai felsőoktatásban kívánták folytatni tanulmányaikat. A külső független tesztelés hivatalos honlapján Ukrajna valamennyi iskolájának összesített eredménye megtalálható. A statisztikai adatok alapján jól kirajzolódik, hogy 2015-ig a magyar tannyelvű iskolák végzős diákjainak jelentős része nem jelentkezik be a független tesztvizsgára. Feltehetően ezek a diákok Magyarországon kívánják folytatni tanulmányaikat.

Jelenleg minden érettségiző számára kötelező részt venni a független tesztvizsgákon, függetlenül attól, hogy nem ukrajnai felsőoktatási intézményben kíván továbbtanulni, vagy esetleg nem is szándékozik jelentkezni egyetemre vagy főiskolára. A 2017/18-as tanévben három tárgyból kell emelt szinten érettségit tenni a végzős diákoknak. Az ukrán nyelv és irodalom továbbra is mindenki számára kötelező, a másik tárgy választhatóan Ukrajna történelme, matematika vagy biológia. Harmadik vizsgatárgyat abban az esetben kell választani, ha az érettségiző felsőoktatási intézményben kíván továbbtanulni. A független tesztvizsgán elért eredmények a felvételi pontszámokat és az érettségi jegyeket is jelentik [Szamborovszky, 2013; Orosz, 2015; Csete, Papp \& Setényi, 2010; Ukrán Oktatásminőség-értékelő Központ; Ukrajna Oktatási és Tudományos Minisztériuma: A 2018-as felvételi feltételei (Web17)].

Malyarenko (2013) tanulmányában jól bemutatja, hogy a 2004-es narancsos forradalom győztesei létrehoztak ugyan egy nemzetiségi és vallásügyekkel foglalkozó állami főhatóságot (2006), viszont ezt az oroszbarát Viktor Janukovics elnök 2010-ben megszüntette. A Juscsenko vezette narancsos koalíció és a Janukovics-féle Régiók Pártja követte azt az 1991 óta tartó gyakorlatot, amely a kisebbségpolitikát az aktuális politikai csatáro zások eszközévé silányította. A rivális felek az etnikai mobilizációt használták fel hatalmi pozíciójuk megtartására, ami politikai instabilitáshoz és társadalmi konfliktusokhoz vezetett. Az ukrán kisebbségpolitikát szabályozó hazai és nemzetközi kötelezettségvállalások ellenére nem jött létre a kisebbségvédelem hatékony mechanizmusa (Malyarenko, 2013). Az oktatás terén a kisebbségi jogokat jelentős mértékben szúkítő intézkedések azt sugallják az országban élő nemzeti kisebbségek felé, hogy csak akkor lehetnek eredményesek, ha feladva anya- 
nyelvüket ukrán tannyelvú iskolákat választanak. Az oktatáspolitikát asszimilációs célokra fordították (Csernicskó, 2009; Kovács, 2014).

\section{Az ukrán oktatáspolitika alakulása a Majdan után}

A Juscsenko elnök és Timosenko miniszterelnök vezette ún. narancsos koalíció a két fél közötti ellentétek kiéleződésével csakhamar ingataggá tette az ukrajnai belpolitikai helyzetet. A hatalomért folytatott küzdelemből a Timosenko vezette BJUT (Julia Timosenko Blokkja) és a Janukovics-féle Régiók Pártja erősödött meg, míg Juscsenko Mi Ukrajnánk mozgalma egyre inkább vesztett népszerűségéből (Jekelcsik, 2014). A következő elnökválasztást (2010) Viktor Janukovics nyerte, s csakhamar a hozzá közel álló Régiók Pártja alakíthatott kormányt. Az elnök tárgyalásokat folytatott az euro-atlanti integrációról, de egy Vlagyimir Putyin orosz államfőtől kapott kecsegtetőbbnek tûnő ajánlat hatására elutasította az Európai Uniós társulási szerződés aláírását (Sz. Bíró, 2014). Janukovics e lépése csalódást keltett a nyugatbarát ukrajnai pártok és állampolgárok körében. 2013 novemberében tüntetések kezdődtek Kijev főterén, a Majdanon. Az ellenzéki ukrán mozgalom, amely élvezte az Európai Unió és az Egyesült Államok támogatását, az Euromajdan elnevezést kapta. A tüntetők oldaláról számos halálos áldozatot követelő eseményeknek nemzetközi közbenjárással próbáltak véget vetni. Az ukrán parlament február 22-én megfosztotta elnöki hatalmától Janukovicsot, s az államfői teendőket a házelnöki tisztséget betöltő Olekszandr Turcsinov vette át. Az Euromajdant támogató erők koalíciós kormányt alakítottak, melynek élére az ukrán törvényhozás Arszenyij Jacenyukot választotta (Deák, 2014; Sz. Bíró, 2014; Csernicsko, 2016).

\section{Az ukrajnai nyelvpolitika változása és hatása a kisebbségek oktatására}

2014. február 23-án a Majdan tüntetések után hatalomra került ukrán törvényhozás a 2012-ben elfogadott nyelvtörvény ${ }^{3}$ eltörlését szavazta meg. A határozatot azonban - kül- és belföldi tiltakozások hatására - nem ír ta alá Turcsinov ideiglenes államfő. A kisebbségi nyelvhasználati jogok szúkítésének felvetődése miatt az ország nemzeti kisebbségei, elsősorban az orosz ajkú állampolgárok felemelték hangjukat. A putyini vezetés felségjelzés nélküli alakulatokkal elfoglalta a Krímet, majd ezt követően támogatta a kelet-ukrajnai szakadár megyék (Donyeck és Luhanszk) ukrán kormányerőkkel szembeni fegyveres harcát, előidézve ezzel a máig is tartói „ukrán válságot” (Csernicskó, 2016. Vö. Fedinec, 2015; Laruelle, 2015; Rutland, 2015; Rácz, 2015).

A Majdan óta az Ukrajnában zajló hivatalos nyelvpolitika arról szól, hogy az ukrán vagy az orosz nyelv használatát előmozdítsák a másik nyelv háttérbe szorításával. Az országban a nyelvi jogszabályokat nem következetesen használják. A kérdés folyamatosan kampánytémává vált, elterelve ezzel a figyelmet az országban jelenlévő gazdasági és szociális problémákról. Ennek hatására az átpolitizált nyelvkérdés 2014-ben a politikai válság és a fegyveres konfliktus kitörésének egyik indoka volt. Míg a válságot követő közvetlen időszakban inkább az orosz kisebbség került az ukrán nacionalisták célkeresztjébe, addig az idő múlásával egyre inkább felerősödtek azok a hangok, amelyek a többi ukrajnai kisebbség nyelvhasználatának korlátozására törekedtek. A későbbiekben a kárpátaljai magyarság vezetői tiltakoztak a leghevesebben a kisebbségellenes oktatási törvénytervezet ellen. Ennek hátterében az állt, hogy a szovjet időszakban egy jelentős struktúrájú (66 magyar tannyelvű, 50

3. A Viktor Janukovics elnök idején hatályba lépő (2012. augusztus 10.) nyelvtörvény az ukrán mint államnyelv mellett 18 regionális vagy kisebbségi nyelvet - köztük a magyart - sorolja fel. A törvény lehetőséget ad a regionális vagy kisebbségi nyelv állami és önkormányzati hivatalokban való használatára, amennyiben az adott közigazgatási egységben a jogszabályban feltüntetett „nyelvek közül egy (vagy több) anyanyelvi beszélőinek aránya eléri a 10\%-ot" (Csernicsko \& Fedinec, 2015. 219-220.). 
vegyes tannyelvű iskola), magyar tannyelvű közoktatási rendszert építettek ki, amelynek működése elé egészen a közelmúltig nem gördített komoly akadályokat az ukrán állami politika.

Az országban felerősödő nacionalista irányvonal és az ukrán oktatásügyben uralkodó áldatlan állapotok reformok bevezetését tették szükségessé. Ennek nyomán új oktatási törvényt dolgoztak ki, amely 2016 áprilisában került a törvényhozás napirendjére. Az ukrán parlament első olvasatban 2016. október 6-án, második olvasatban 2017. szeptember 5-én fogadta el az új oktatási törvényt. Ennek értelmében a jelenlegi 11 évfolyamos középiskolai oktatást 12 évesre kell átalakítani. Az új struktúra szerint továbbra is az 1-4. osztály lesz az elemi iskola, az 5-9. osztály pedig az általános iskola. A középiskolai oktatás harmadik fázisában mutatkozik majd eltérés, ahol 10-12. évfolyamon választhatóan szakiskolában vagy érettségit nyújtó líceumokban lehet továbbtanulni. Az új törvény előírásait fokozatosan vezetik be, a legfontosabb változások beindítása 2018. szeptember 1-től vannak előírva (Fedinec \& Csernicskó, 2017).

A törvény 7. cikkelye foglalkozik a tannyelvvel. Ez a passzus drasztikus módon csökkenti a kisebbségek nyelvén folyó oktatási jogot. A 7. cikkely értelmében a nemzeti kisebbségekhez tartozók, úgy mint a bizonyos területen tömbben élő oroszok, magyarok, románok stb. számára csak az 1-4. osztályban, tehát elemi szinten garantált az a jog, hogy anyanyelvükön tanuljanak. A törvény 7. cikkelyének értelmében a felsőoktatásban is megszúnik a kisebbségek anyanyelvi oktatása. A szükséges ismereteket a kárpátaljai magyar fiataloknak - az Ukrajnában élő nemzeti kisebbségi sorstársaikhoz hasonlóan - egy számukra idegen nyelven kell elsajátítaniuk. Ennek bevezetése az állampolgárok közötti esélyegyenlőség látszatát is megszüntetné. Az Ukrajnában kialakult válság során az orosz kisebbségre is kiterjedtek a megszorítások. Az Ukrajnában élő kisebbségek közül csupán az oroszok tehettek anyanyelvükből független emelt szintú érettségi vizsgát, 2018-tól azonban tőlük is elvették ezt a lehetőséget, s csak angol, német, francia és spanyol nyelvek közül lehetett választani. A versenyképes tudás megszerzése csak az ukrán nyelv megfelelő szintű ismeretével valósulhatna meg. Az új törvény szellemiségét markánsan képviselő Lilija Hrinevics, jelenlegi ukrán oktatásügyi miniszter szerint ennek módja az, hogy az ötödik osztálytól kezdve az államnyelv válna az oktatás nyelvévé, függetlenül attól, hogy az adott iskola tanulói ukránok, oroszok, magyarok, románok, szlovákok, lengyelek (Hodinka 2017).

Az oktatási minisztérium adatai szerint Ukrajnában a tanulók 89,9\%-a ukrán tannyelven tanul. Csupán az ukrajnai tanulók 10,71\%-a tanul más tannyelven. Mégis azt feltételezik, hogy az ukrán nyelv fejlődését, az anyanyelv funkcióit az ország tanulóinak tized része veszélyezteti. 


\begin{tabular}{|lrr|}
\hline \multicolumn{1}{c}{ Tannyelv } & Tanulók száma & Aránya (\%) \\
\hline Ukrán & 3281644 & 89,29 \\
\hline Orosz & 356262 & 9,69 \\
\hline Román & 16808 & 0,46 \\
\hline Magyar & 15172 & 0,41 \\
\hline Moldáv & 2984 & 0,08 \\
\hline Lengyel & 1594 & 0,04 \\
\hline Angol & 400 & 0,01 \\
\hline Szlovák & 134 & 0,00 \\
\hline Bolgár & 78 & 0,00 \\
\hline Összesen & 3675076 & 100 \\
\hline
\end{tabular}

2. táblázat. Az ukrajnai iskolák tanulóinak száma nemzetiségi megoszlás szerint. Forrás: Ukrán Oktatásügyi Minisztérium adatai alapján saját szerkesztés

A szeptember 5-én elfogadott új oktatási törvény 7. cikkelye több jogi normával is szembemegy: ellentmond a Moldáviával, Romániával és Magyarországgal kötött kétoldalú szerződéseknek s azon ukrán törvénycikkelyeknek, amelyek biztosítják a nemzeti kisebbségek nyelvi jogainak védelmét. Ezen kívül az Ukrajnában élő nemzeti kisebbségekre vonatkozó törvényben szerepel, hogy az ukrán állam minden etnikum számára garantálja a nemzeti kulturális autonómiát. Mindez magában foglalja az anyanyelv használatát és az azon való ta nulást az állami intézményekben. Ukrajna számos nemzetközi jogegyezményt ratifikált, amelyek közvetlen hatással vannak a nemzeti kisebbségek nyelvére. A regionális vagy kisebbségi nyelvek európai kartája magában fogIalja a nemzeti kisebbségek védelméról szóló keretegyezményt, a nemzeti vagy etnikai, vallási és nyelvi kisebbségekhez tartozó személyek jogairól szóló nyilatkozatot, az emberi és alapvető szabadságjogok védelméről szóló egyezményt. Az új oktatási törvény szembemegy az ország nemzetközi szerződésekben vállalt kötelezettségeivel, amelyek megtalálhatók Ukrajna Alkotmányában.

\section{Elvándorlási hajlandóság}

2014 tavaszán Ukrajnában elkezdődtek a katonai besorozások, így Kárpátalja magyar ifjai külföldön vállaltak munkát. Mára a harcok csendesedtek, azonban Ukrajna keleti részén máig vannak összecsapások. A háborús helyzet miatt az ország keleti feléről nyugat felé menekülnek az emberek. A politikai események következtében az országot súlyos gazdasági válság sújtja.

Ukrajna Ifjúsága - 2015 (Молодь України - 2015) címmel szervezett kutatást Ukrajna Ifjúsági és Sportminisztériuma. A minisztérium honlapján ukrán és angol nyelven elérhetőek a kutatás eredményei. A kutatás során 285214 és 35 év közötti ukrán fiatalt kérdeztek társadalmi aktivitás, mobilitás, migrációs törekvések, hazafias érzelmek, anyagi helyzet, oktatás, képzés, munkavállalás, egészségi állapot, sportolási szokások, ifjúságpolitika témakörökben. A kutatás eredményei alapján jól kirajzolódik, hogy a 2013 tavaszán kezdődött Euromajdan, a Krím megszállása, illetve a 2014 tavaszától tartó „hibrid háború” miatt az ukrán fiatalok körében felerősödött a hazafias öntudat. A megkérdezettek 44\%-a nem szeretné elhagyni Ukrajnát, 38\% tervezi, hogy bizonyos időre külföldre megy tanulni vagy dolgozni, $13 \%$ lehetőséget keres, hogy el tudja hagyni az országot, 4\% pedig a lehető leghamarabb emigrálni akar Ukrajnából. Az országukat elhagyni kívánó fiatalok 58\%-a nem tartja megfelelőnek a munkalehetőségeket, illetve az életkörülményeket, a megkérdezettek 56\%-a pedig azon 
az állásponton van, hogy Ukrajnában hiányzik a demokrácia és a jogállamiság. Ennek következtében elhatározzák a kivándorlást (Volosevits et al. 2015. Vö. Csernicskó \& Hires László, 2017).

2016-ban a kijevi oktatási tárca kérésére ismét elvégezték a kutatást, azonban az „ideiglenesen” orosz meg szállás alatt lévő Krím, Luhanszk és Donyeck megye nem kapcsolódott be a kutatásba. Ennek eredményeképpen kisebb reprezentatív mintát vettek alapul, mintegy 1200 fiatalt kérdeztek meg a kutatás során. Az eredmények alapján a megkérdezettek 44,9\%-a Ukrajnában kíván élni, 28,3\% tervezi, hogy bizonyos időre külföldre megy, 12,3\% tervezi, hogy bizonyos időre külföldre megy tanulni vagy dolgozni, 12,3\% lehetőséget keres az emigrálásra, 4,2\% a lehető leghamarabb el akarja hagyni az országot (Dmytruk, Padalka, Kiryev, Mostova, Bikla \& Selepea, 2016).

Az Euromajdant követő években a kárpátaljai magyar fiatalok körében felerősödött az emigráció, s legtöbb ször Magyarországot célozzák meg. A továbbtanulni vágyó fiatalok körében megkönnyíti az elmozdulási hajlandóságot a magyar állam által biztosított támogatáspolitika. 2010-ben elfogadták a visszahonosítási törvényt, a kárpátaljai magyarságnak is lehetősége nyílt a kettős állampolgárság megszerzésére. Ennek következtében a kárpátaljai fiatalok számos külföldi munkalehetőséget ragadtak meg.

\section{Konklúzió}

Az ukrajnai oktatáspolitikát a kisebbségi nemzeti közösségek szempontjából kettősség jellemzi: egyszerre megfigyelhető az európai hatás és az ukránosítás. A politikai és gazdasági változások során számos pozitív cél kitúzést hajtottak végre az oktatáspolitika terén. Ide sorolhatók az Európai Unió felé nyitó lépések, mint például a Bolognai-rendszerhez történő csatlakozás. Hiába mondható el azonban, hogy az ország oktatáspolitikai szempontból az Európai Unió felé törekszik, mivel meglátásunk szerint a kisebbségek jogait illetően visszafejlődés tapasztalható. Beigazolódik Papp Z. (2008) írása, miszerint a szovjet érából megmaradó rendszer, a független Ukrajnában bekövetkező változások és az Európai Unióval kötött szerződésekből fakadó kötelezettség öszszeegyeztetése miatt kialakuló konfliktusok instabillá tették az ukrajnai kisebbségek oktatáspolitikai helyzetét.

A kárpátaljai magyarság Ukrajnán belül speciális helyzetet tudhat magáénak. Kárpátalja Ukrajna legnyugatibb megyéje. Az ukrajnai közigazgatási egységek közül e megyének van a legtöbb Európai Uniós országgal ha tára. Ebben a közigazgatási egységben a magyarság száma meghaladja a 10 százalékot. Az oktatáspolitika az itt élő magyarokra nemzeti kisebbségként tekint, nem pedig őshonos lakosságként tartják őket számon. A kárpátaljai magyarság megörökölt jogokat élvezett a rendszerváltást követő években. A Szovjetunióban biztosított ki sebbségi jogok megmaradtak az országban. Leonyid Kucsma elnöksége (1996-2004) idején ezeket a jogokat nem is feszegették; ebben az időszakban kisebbségpolitikával nem foglalkoztak. A függetlenség elóestéjén a kárpátaljai magyarság rendelkezett magyar tannyelvú óvodákkal és iskolákkal, mégsem volt teljes körú iskolahálózatuk, ugyanis nem működött magyar tannyelvű felsőoktatási intézmény. A rendszerváltást követő években tovább működtek a magyar tannyelvű oktatási intézmények és felsőoktatási intézmény létrehozására is igény született. A magyar tannyelvű főiskolát az Európán végigsöprő felsőoktatási expanzió hatására meg is valósították.

A narancsos forradalom célul tǔzte ki az Európai Unióhoz való közeledést. Ám az akkor hatalomra kerülő erők kétarcúságára jellemző, hogy a nagypolitikában hangoztatott demokratikus változások meghirdetésével párhuzamosan a háttérben, ebben az időszakban kezdődött meg a kisebbségi jogok korlátozása.

Az Euromajdan során gazdasági és politikai értelemben erőteljesebb Nyugathoz fordulás figyelhető meg. Az Európai Unióval különböző társulási szerződések jöttek létre. A nyugati értékek iránti elköteleződés azonban 
nem valósult meg, s ez leginkább a kisebbségi politikában tapasztalható. Az ukrajnai háború következtében a kijevi vezetés bizalmatlan lett a kisebbségek irányában, fóleg az orosz kisebbséggel szemben. A kialakult bizalmatlan légkör negatívan hat a kárpátaljai magyarság országos megítélésére is. Ez abban is megnyilvánul, hogy a korábban élvezett jogokat egyre inkább korlátozzák, dacára annak, hogy az ország nemzetközi kötelezettségeket tett ezek megvalósítására (A regionális vagy Kisebbségi Nyelvek Európai Kartája, a Moldáviával, Romániával és Magyarországgal kötött kétoldalú szerződéseknek s azon ukrán törvénycikkelyeknek, amelyek biztosítják a nemzeti kisebbségek nyelvi jogainak védelmét).

\section{Irodalom}

1. Bacskai, K. Morvai, T. \& Csánó J. (2015). Pedagógushallgatók a kisebbségi és többségi felsőoktatásban. In Pusztai, G. \& Ceglédi, T. (Eds.), Szakmai szocializáció a felsőoktatásban. A pedagógusképzés kihívásai a Kárpát-medencében (pp. 224-241). Nagyvárad-Budapest: Partium-PPS-UMK.

2. Bárdi, N. \& Misovicz, T. (2010). A kisebbségi magyar közösségek támogatásának politikája. In Bitskey, B. (Ed.), Határon túli magyarok a 21. században (pp. 66-76). Budapest: KEH.

3. Beregszászi, A. \& Csernicskó, I. (2007). A Regionális és Kisebbségi Nyelvek Európai Kartája - ukrajnai módra. Kisebbségkutatás, 2, 251-261.

4. Csernicskó, I. \& Hires László, K. (2017). Ifjúságkutatások Ukrajnában és Kárpátalján. In Papp Z., A. (Ed.), Változó kisebbség. Kárpát-medencei magyar fiatalok. A GeneZYs 2015 eredményei (pp. 171-191). Budapest: MTA Társadalomtudományi Kutatóközpont Kisebbségkutató Intézet.

5. Csernicskó, I. \& Melnyk, S. (2007). Az ukrajnai kisebbségek és a nyelvi oktatás. In Orosz, I. (Ed.): Magyarok a Tisza-forrás környékén. A felső-Tisza-vidéki magyarok anyanyelvi-oktatási helyzete egy kutatás tükrében (pp. 120-148). Ungvár: PoliPrint Kiadó.

6. Csernicskó, I. (2009). Az ukrajnai oktatáspolitika a nyelvi asszimiláció szolgálatában. Korunk, 2, 33-40.

7. Csernicskó, I. (2012). Megtanulunk-e ukránul? A kárpátaljai magyarok és az ukrán nyelv. Ungvár: PoliPrint Kiadó.

8. Csernicskó, I. (2014). Magyar nyelvű felsőoktatás Kárpátalján: kihívások, perspektívák. In: Kónya, P. (Ed.), Univerzita v kontexte zmien: Zborník príspevkov z mezdinárodnej vedeckej konferencie, konanej 28 30. novembra 2012 v Prešove (pp. 341-354).Presov: Vydavatelstvo Presovskej Univerzity.

9. Csernicskó, I. (2016). Nyelvpolitika a háborús Ukrajnában. Ungvár: Autdor-Shark.

10. Csete, Ö. Papp Z., A. \& Setényi, J. (2010). A kárpát-medencei magyar oktatás az ezredfordulón. In Bitskey, B. (Ed.), Határon túli magyarok a 21. században (pp. 44-55). Budapest: KEH.

11. Deák, A. (2014). Kifulladásig - Az orosz-ukrán konfliktusról. Figyelő, 36, 18-19.

12. Dmytruk = Дмитрук, Н. \& Падалка, Г. \& Кірєєв, С. \& Мостова, І. \& Бікла, О. \& Шелепа, В. (2016). Цінності української молоді. Результати репрезентативного соціологічного дослідження становища молоді. Київ: Міністерство молоді та спорту України.

13. Fedinec, Cs. \& Csernicskó, I. (2017). A 2017-es ukrajnai oktatási kerettörvény: a szöveg keletkezéstörténete és tartalma. Regio, 3, 278-300.

14. Fedinec, Cs. (2012). Ukrajna helye Európában és a magyar-ukrán kapcsolatok két évtizede. Külügyi Szemle, 4, 99-123.

15. Fedinec, Cs. (2015). A háború, melyet ukrán válságnak neveznek. Új Egyenlítő. 2-3, 45-48.

16. Ferenc, V. (2009). Hungarian Higher Education in Ukraine: Arguments for and Against. In Pajusalu, K. (Ed.), 12th International Conference on Minority Languages: Cenference Abstracts. (pp. 53-55). Tartu: University of Tartu.

17. Ferenc V. (2010). A kisebbségi magyar felsőoktatás és nyelvi kihívásai a Kárpát-medencében: problémák és feladatok. Regio, 3, 59-89. 
18. Filiatreau, S. (2011). Ukraine"s Participation in the Bologna Process: Has it Resulted in More Transparency in Ukrainian Higher Education Institutions? International Research and Review: Journal of Phi Beta Delta Honor Society of International Scholars, 1, 49-64.

19. Hrubos, I. (2005). A peregrinációtól az Európai Felsőoktatási Térségig. Educatio, 2, 223-243.

20. Jekelcsik, Sz. (2014). Ukrajna története. Egy modern nemzet születése. Budapest: Kairosz Kiadó

21. Kalóczi, K. \& Kulcsár Szabó, E. (2016). A határon túli magyar oktatás, kultúra és tudományosság magyarországi támogatása az 1990-es években. In Fedinec, Cs. (Ed.), A nemzet mint tudományos közösség. Húszéves a Magyar Tudományos Akadémia Magyar Tudományosság Külföldön Elnöki Bizottsága 1996-2016 (pp. 13-35). Budapest: MTA Magyar Tudományosság Külföldön Elnöki Bizottság.

22. Keller, M. (2004). Magyar nyelvű pedagógusképzés a határokon túl. Educatio, 3, 441-462.

23. Kovács, K. (2014). The Bologna Process in Ukraine. In Kozma, T., Rébay, M., Óhidy, A. \& Szolár, É. (Eds.), The Bologna Process in Central and Eastern Europe (pp. 321-354). Wiesbaden: Springer VS.

24. Kozma, T. (2006). Regionális átalakulás és térségi visszhang. A „partiumi” felsőoktatás esete. In Juhász, E. (Ed.), Régió és oktatás. A „Regionális egyetem” kutatás zárókonferenciájának tanulmánykötete. (pp. 13-25). Debrecen: Doktoranduszok Kiss Árpád Közhasznú Egyesülete.

25. Kozma, T. (2010). Expanzió Tények és elörejelzések, 1983-2020. Educatio, 1, 7-18.

26. Kozma, T. (2011). Kisebbségi intézmények a Bologna-folyamatban. In Kozma, T. \& Pataki, Gy. (Eds.), Kisebbségi felsőoktatás és a Bologna-folyamat (pp. 45-74). Debrecen: CHERD-Hungary.

27. Kozma, T. (2012). Oktatáspolitika. Debrecen - Pécs: k. n.

28. Laruelle, M. (2015). The Ukrainian Crisis and its Impact on Transforming Russian Nationalism. In: Pikulicka-Wilcewska, A. - Sakwa, R. (Eds.), Ukraine and Russia: People, Politics, Propaganda and Perspectives (pp. 123-128). Bristol: E-International Relations Publishing.

29. Luchinskaya, D. \& Ovchynnikova, O. (2011). The Bologna Process Policy Implementation in Russia and Ukraine: similarities and differences. European Educational Research Journal, 10, 21-33.

30. Malyarenko, T. (2013): Between the Soviet legacy and opportunism. Minority policy in Ukraine. In Cordell, K. \& Agarin, T. \& Osipov, A. (Eds.), Institutional Legacies of Communism: Change and Continuities in Minority Protection (pp. 139-153). London: Routledge.

31. Orosz, I., Beregszászi, A., Csernicskó, I. \& Bátyi, Sz. (2011). A magyar oktatás Kárpátalján. In Bartha, Cs., Nádor, O. \& Péntek, J. (Eds.), Nyelv és oktatás kisebbségben: Kárpát-medencei körkép (pp. 213-277). Budapest: Tinta Könyvkiadó.

32. Orosz, I. (2005). A magyar nyelvú oktatás Kárpátalján az ukrán államiság kialakulásának első évtizedében. Ungvár: PoliPrint.

33. Orosz, I. (2007). A függetlenségtól a narancsos forradalomig. Ungvár: PoliPrint.

34. Orosz, I. (2012). A magyar nyelvű oktatás helyzete. In: Uő. (Ed.), Két évtized távlatából (pp. 192-193). Ungvár: PoliPrint.

35. Orosz, I. (2015). Magyar nyelvú pedagógusképzés Kárpátalján. In Pusztai, G. \& Ceglédi, T. (Eds.), Szakmai szocializáció a felsőoktatásban. A pedagógusképzés kihívásai a Kárpát-medencében (pp. 52-64). Nagyvárad-Budapest: Partium-PPS-UMK.

36. Papp Z. A. (2008). A kisebbségi oktatás politikai, jogi, társadalmi keretei. In: Bárdi N. - Fedinec Cs. \& Szarka, L. (Eds.), Kisebbségi magyar közösségek a 20. században (pp. 384-389). Budapest: Gondolat Kiadó - MTA Kisebbségkutató Intézet.

37. Papp Z. A. (2014). Oktatáspolitikai koncepciók kisebbségben külhoni és anyaországi változások. Educatio, 1, 67-80.

38. Rácz, A. (2015). Russia's Hybrid War in Ukraine. Breaking the Enemy's Ability to Resist. Helsinki: The Finnish Institute of International Affairs. 
39. Rutland, P. (2015). An Unnecessary War: The Geopolitical Roots of the Ukrainian Crisis. In: PikulickaWilcewska, A. \& Sakwa, R. (Eds.), Ukraine and Russia: People, Politics, Propaganda and Perspectives (pp. 129-140.) Bristol: E-International Relations Publishing.

40. Sz. Bíró, Z. (2014): Ukrajnai tanulságok. Mozgó Világ, 1, 72-78.

41. Szamborovszkyné Nagy, I. (2013). Oktatáspolitika és történelemtanítás a Szovjetunióban és Ukrajnában (1945-2010). I-II. Szovjetunió (1945-1991). Ukrajna (1991-2010). Ungvár: „Líra” Poligráfcentrum.

42. Vámos, Á. (2016). Kétnyelvǔ oktatás Magyarországon tannyelvpolitika, tannyelvpedagógia. MTA doktori értekezés. Kézirat. Retrieved from: http://real-d.mtak.hu/984/ (2017. 01. 12.)

43. Volosevits = Волосевич, І., Герасимчук, С. \& Костюченко, Т. (2015): Молодь України - 2015. [Ukrajna Ifjúsága-2015] Київ: Міністерство молоді та спорту України.

Internetes források

1. Web1. Ukrajna alkotmánya = КОНСТИТУЦІЯ УКРАїНИ (Відомості Верховної Ради України (ВВР), 1996, № 30, ст. 141. Retrieved from: http://zakon0.rada.gov.ua/laws/show/254\%D0\%BA/96\%D0\%B2\%D1\%80. (2017. 01. 12.)

2. Web2. Ukrajna elnökének törvényerejü rendeletei és rendelkezései = Президент України «Укази» Retrieved from: http://www.president.gov.ua/documents/decrees. (2017. 06. 14.)

3. Web3. Ukrajna Alkotmánybíróságának végzései = Рішення Конституційного Суду України. Retrieved from:: http://www.ccu.gov.ua/docs/9. (2017. 06. 14.)

4. Web4. Ukrajna Miniszteri Kabinetjének határozatai = Рішення Уряду. Retrieved from: https://www.kmu.gov.ua/ua/npasearch. (2017. 06. 14.)

5. Web5. Ukrajna Oktatási és Tudományos Minisztériuma rendeletei és határozatai = Міністерство освіти і науки Укрпаїни. Законодавство: Retrieved from: https://mon.gov.ua/ua/npa. (2017. 06. 14.)

6. Web6. 34. számú törvény = Відомості Верховної Ради УРСР (ВВР), 1991, № 34, ст. 451. Retrieved from: : http://zakon5.rada.gov.ua/laws/show/1060-12. (2017. 01. 02.)

7. Web7. A regionális vagy Kisebbségi Nyelvek Európai Karta = Закон України «Про ратифікацію Європейської хартії регіональних мов або мов меншин» Retrieved from: https://webcache.googleusercontent.com/search?q=cache:ZE38TKlc6gAJ:https://www.ajbh.hu/ documents/10180/122652/Regionalis\%2Bvagy\%2Bkisebbse\%25CC\%2581gi\%2Bnyelvek\%2BEuro \%25CC\%2581pai\%2BCharta\%25CC\%2581ja.pdf/e70ba9fb-e1d5-465c-b00c50713fef64e2\%3Fversion\%3D1.0\%26download\%3Dtrue+\&cd=2\&hl=hu\&ct=clnk\&gl=ua (2017. 01. 14.)

8. Web8. 1350-XIV. számú törvény = Закон України «Про ратифікацію Європейської хартії регіональних мов або мов меншин» (Відомості Верховної Ради України (ВВР), 2003, N 30, ст. 259). Retrieved from: http://zakon3.rada.gov.ua/laws/show/1350-14. (2017. 01. 14.)

9. Web9. N 802-IV. számú törvény = Про ратифікацію Європейської хартії регіональних мов або мов меншин. Retrieved from: http://zakon0.rada.gov.ua/laws/show/802-15

10. Web10. Ukrajna alkotmánya = Конституція України. Retrieved from: http://zakon3.rada.gov.ua/laws/ show/254\%D0\%BA/96-\%D0\%B2\%D1\%80

11. Web11. 36. számú rendelet = Відомості Верховної Ради України (ВВР), 1992, N 36, ст.529. Retrieved from: http://zakon3.rada.gov.ua/laws/show/2494-12.

12. Web12. Bethlen Gábor Alapkezelő Zrt. Retrieved from: http://bgazrt.hu/_files/NPKI/oktatas/Magyarukr\%C3\%A1n\%20alapszerz\%C5\%91d\%C3\%A9s.pdf.

13. Web13. Ukrajna felsőoktatási törvénye = Закон України «Про вищу освіту» (Відомості Верховної Ради (ВBP), 2014, № 37-38, ст.2004). Retrieved from: http://zakon3.rada.gov.ua/laws/show/155618. 
14. Web14. „Az ukrajnai oktatás múködését és fejlödését biztositó elengedhetetlen intézkedésekről” = Пpo невідкладні заходи щодо забезпечення функціонування та розвитку освіти в України. Retrieved from: http://zakon3.rada.gov.ua/laws/show/1013/2005.

15. Web15. 1171-es rendelet = Наказ 25.12.2007 № 1171 «Про зовнішнє незалежне оцінювання навчальних досягнень випускників навчальних закладів системи загальної середньої освіти, які виявили бажання вступати до вищих навчальних закладів у 2008 році». Retrieved from: http://search.ligazakon.ua/I_doc2.nsf/link1/RE14696.html.

16. Web16. 33. számú rendelet: Про затвердження Положення про громадський контроль за проведенням в Україні зовнішнього незалежного оцінювання навчальних досягнень випускників загальноосвітніх навчальних закладів і зарахуванням до вищих навчальних закладів. Retrieved from: https://zakon5.rada.gov.ua/laws/show/z0321-08.

17. Web17. Ukrajna Oktatási és Tudományos Minisztériuma: A 2018-as felvételi feltételei = Міністерство освіти і науки: Умови прийому до вищих навчальних закладів в 2018 році. Retrieved from: https:// mon.gov.ua/ua/osvita/visha-osvita/vstupna-kampaniya-2018/umovi-prijomu-na-navchannya-dozakladiv-vishoyi-osviti-ukrayini-v-2018-roci. [Letöltés ideje: 2017. 01. 14.]

18. Web18. Ukrán Oktatás-minőségértékelő Központ = Український центр оцінювання якості освіти. Retrieved from: http://testportal.go.ua/about/.

\section{The Impact of Ukraine's Education Policy on Hungarian Higher Education in Transcarpathia}

The minority policy and the influence of the education policy on it play a particularly important role since they are found in a specific field (Kozma, 2012). This study would like to demonstrate the Ukrainian education policy from the transition until now (1991-2018). We would like to reveal the development of the Ukrainian education policy approaching towards European Union standards, how serious the Ukrainian parliament was about putting its commitments into effect and how successful these efforts were. We tend to examine what influence the different political changes had on the minority policy of the Ukrainian state, especially on the Hungarians. We highlight the main directives and tendencies. The Ukrainian education policy is ambiguous from the perspective of minority communities: the European effect and the Ukrainian dominance are also observed. During the political and economic changes several positive objectives are implemented in the field of education policy. These include the initial steps towards the Europian Union and joining the Bologna system. The country approaches the Europian Union from the perspective of the education policy, but our results confirm the regression in the field of the rights of minority communities.

Keywords: education policy, rights of minority communities, Ukraine 